Cornell University Law School Scholarship@Cornell Law: A Digital Repository

\title{
Second-Order Linking Principles: Combining Vertical and Horizontal Modes of Liability
}

Jens David Ohlin

CornellLaw School,jdo43@cornell.edu

Follow this and additional works at: http://scholarship.law.cornell.edu/facpub

Part of the Criminal Law Commons, and the International Law Commons

\section{Recommended Citation}

Ohlin, Jens David, "Second-Order Linking Principles: Combining Vertical and Horizontal Modes of Liability" (2012). Cornell Law Faculty Publications. Paper 577.

http://scholarship.law.cornell.edu/facpub/577

This Article is brought to you for free and open access by the Faculty Scholarship at Scholarship@Cornell Law: A Digital Repository. It has been accepted for inclusion in Cornell Law Faculty Publications by an authorized administrator of Scholarship@Cornell Law: A Digital Repository. For more information, please contact jmp8@cornell.edu. 


\title{
INTERNATIONAL CRIMINAL COURT AND \\ TRIBUNALS
}

\section{Second-Order Linking Principles: Combining Vertical and Horizontal Modes of Liability}

\author{
JENS DAVID OHLIN*
}

\begin{abstract}
Both the International Criminal Tribunal for the former Yugoslavia (ICTY) and the International Criminal Court (ICC) have struggled to combine vertical and horizontal modes of liability. At the ICTY, the question has primarily arisen within the context of 'leadership-level' joint criminal enterprises (JCEs) and how to express their relationship with the relevant physical perpetrators (RPPs) of the crimes. The ICC addressed the issue by combining indirect perpetration with co-perpetration to form a new mode of liability known as indirect co-perpetration. The following article argues that these novel combinations - vertical and horizontal modes of liability - cannot be simply asserted; they must be defended at the level of criminal-law theory. Unfortunately, courts that have applied indirect co-perpetration have generally failed to offer this defence and have simply assumed that modes of liability can be combined at will. In an attempt to offer the needed justification, this article starts with the premise that modes of liability are 'linking principles' that link defendants with particular actions, and that combining these underlying linking principles requires a second-order linking principle. The most plausible candidate is the personality principle - a basic principle that recognizes the inherently collective nature of leadership-level groups dedicated to committing international crimes. Like Roxin's theories describing the collective organizations that can be used as a form of indirect perpetration, the personality principle treats the horizontal leadership group as an organization or group agent whose collective nature potentially justifies the attribution of vertical modes of liability to all members of the horizontal group. Although this article does not defend the doctrine of indirect co-perpetration, it does conclude that combined vertical and horizontal modes of liability, whether at the ICTY or ICC, implicitly or covertly rely on something like the personality principle in order to justify collective attribution to the horizontal collective.
\end{abstract}

\section{Key words}

co-perpetration; control theory of perpetration; indirect co-perpetration; indirect perpetration; JCE; joint criminal enterprise; modes of liability

* Associate Professor of Law, Cornell Law School [jens-ohlin@lawschool.cornell.edu]. I am grateful for comments and suggestions from Boris Burghardt, Lori Damrosch, George Fletcher, Jean Galbraith, Florian Jeßberger, Elies van Sliedregt, and James Stewart, as well as students in the Jurisprudence of War seminars at both Columbia Law School and Cornell Law School. Sarah Heim provided invaluable research and translation assistance. 


\section{INTRODUCTION}

One way of characterizing modes of liability is to think of them as linking principles. The criminal law is obsessed with linking: linking defendants with particular acts; linking criminals to other criminals (for purposes of derivative or vicarious liability); linking past decisions with future consequences, either foreseen or unforeseen; linking punishment with moral desert. In fact, linking principles abound in all areas of the law, both public law and private law, whenever actions are linked in some way with legal responsibility. The underlying legal doctrines used to perform this function are all, in a sense, linking principles.

Modes of liability represent a special kind of linking principle of particular concern to criminal lawyers. Modes of liability form an essential ingredient of the criminal law's language of culpability. Although actus reus, mens rea, and attendant circumstances are important, modes of liability are the glue that holds it all together. Without them, defendants are just subjects without predicates.

There is a particular reason for looking at modes of liability as one specific variety of the more general category of linking principles. In the recent development of the international criminal jurisprudence on collective action, courts and scholars have started to combine modes of liability, forming new and innovative modes of liability out of the building blocks of past theories and precedents. While these ad hoc combinations are often creative solutions to the riddle of collective criminal action, very little attention has been paid to providing a general account of when and how modes of liability can be combined. By discussing modes of liability within the more general context of linking principles, it is hoped that a general justification for this practice can be provided. This general justification is a 'second-order' linking principle that will link two 'first-order' linking principles together.

This article concentrates on one combination of particular importance for international courts. In many criminal cases, a mode of liability links one leadership-level defendant with a vertical organization that extends all the way from the leadership down to the physical perpetrators who actually pull the trigger. Then, another mode of liability horizontally links the defendant to other political or military leaders, who might also be convicted for the crimes committed by the physical perpetrators. This general structure of combined vertical-horizontal liability has multiple instantiations, although the two best-known examples involve joint criminal enterprise (JCE), applied primarily by the International Criminal Tribunal for the former Yugoslavia (ICTY) and other ad hoc tribunals, and indirect co-perpetration applied by the International Criminal Court (ICC) Pre-Trial Chamber.

Consequently, section 2 of this article will explain how JCE originally obviated the need for vertical and horizontal combinations, but recent developments in the doctrine 'de-linked' the leadership defendants from the physical perpetrators, thus creating the problem of vertical and horizontal linkage that remains unsolved in ICTY jurisprudence. Section 3 will then critically analyse the ICC's solution to this problem: the ad hoc combination of vertical indirect perpetration with horizontal co-perpetration, thus creating the ad hoc combination of indirect co-perpetration. Particular attention will be paid to the diverse structures that such 
horizontal-vertical combinations can take. Finally, section 4 will conclude that only a second-order linking principle - the personality principle - can provide a normative justification for combining vertical and horizontal modes of liability. The personality principle appeals to the collective nature of the horizontal leadership group as the basis for a mutual attribution of responsibility for crimes physically perpetrated by one of the vertical branches.

\section{VertiCAL Linking at THE ICTY}

In an influential decision, an ICTY Trial Chamber in Brdanin rejected the application of JCE to the defendant because there was no explicit agreement between the defendant and the relevant physical perpetrators, or what the Trial Chamber referred to as the RPP. ${ }^{\mathrm{I}}$ In the absence of a direct link between the defendant and the RPP in this case the link was defined as an explicit agreement - the Trial Chamber was unwilling to conclude that the defendant and the RPP were part of the same JCE. ${ }^{2}$ Furthermore, because there was no all-encompassing JCE that included both parties, the defendant could not be vicariously responsible for the actions of the RPP. ${ }^{3}$

On appeal, there were several ways that this holding might have been reversed. First, the Appeals Chamber might have simply disagreed on factual grounds; for example, they could have concluded that there was an explicit agreement between the defendant and the RPP. Second, the Appeals Chamber could have held that a court was entitled to infer agreement based on the surrounding circumstances and the relevant context within which the RPPs were operating. ${ }^{4}$ However, the Appeals Chamber held no such thing. The judges charted a third and far more daring path: it was not required that the RPP and the defendant belong to the same JCE at all. ${ }^{5}$

This result did far more than simply eviscerate the 'explicit-agreement' requirement applied by the Trial Chamber. Had it done only this, the decision would have had a modest impact on the development of international criminal-law (ICL) jurisprudence on collective action. Rather, the Appeals Chamber move in Brdanin resolved the issue by completely removing the defendant from the relevant

I Prosecutor v. Brdanin, Trial Judgement, Case No. IT-99-36, T.Ch., I September 2004, paras. 347-348: 'The Trial Chamber in this context emphasizes that for the purposes of establishing individual criminal responsibility pursuant to the theory of JCE it is not sufficient to prove an understanding or an agreement to commit a crime between the Accused and a person in charge or in control of a military or paramilitary unit committing a crime.'

2 Ibid., para. 347: 'The Accused can only be held criminally responsible under the mode of liability of JCE if the Prosecution establishes beyond reasonable doubt that he had an understanding or entered into an agreement with the Relevant Physical Perpetrators to commit the particular crime eventually perpetrated or if the crime perpetrated by the Relevant Physical Perpetrators is a natural and foreseeable consequence of the crime agreed upon by the Accused and the Relevant Physical Perpetrators.'

3 Ibid., para. 35I: 'However, the Trial Chamber is of the view that the mere espousal of the Strategic Plan by the Accused on the one hand and many of the Relevant Physical Perpetrators on the other hand is not equivalent to an arrangement between them to commit a concrete crime. Indeed, the Accused and the Relevant Physical Perpetrators could espouse the Strategic Plan and form a criminal intent to commit crimes with the aim of implementing the Strategic Plan independently from each other and without having an understanding or entering into any agreement between them to commit a crime.'

4 See, e.g., Prosecutor v. Brdanin, Partly Dissenting Opinion of Judge Shahabuddeenin, Appeals Judgement, Case No. IT-99-36, A.Ch., 3 April 2007, para. 4 (JCE agreement inferred from circumstances), para. 7.

5 Ibid., para. 4I3. 
JCEs - the only criminal group that encompassed the physical perpetrators and the original source of the criminal responsibility to be vicariously attributed to the defendant. 6

Although this solved one problem (the issue of the explicit agreement), it opened up another: namely the question of how to 'link' the defendant with the RPP so as to justify the attribution of vicarious liability from the RPP to the defendant. Strangely enough, the Brdanin Appeals Chamber showed little interest in providing a coherent and unanimous answer to this question, ${ }^{7}$ preferring instead to leave the matter to individual justices to discuss in separate concurring opinions, ${ }^{8}$ thus leaving no substantial direction for future Trial Chambers in how the doctrinal innovation should be applied. ${ }^{9}$

Why would the Appeals Chamber have gone to such lengths to perform this 'delinking?? ${ }^{\text {Io }}$ Perhaps the Appeals Chamber was motivated by a laudable desire to express a hierarchical difference between the high-level perpetrators, who ought to be defined as principals, and the RPP, who in some ways resemble accomplices in so far as their relative culpability is far lower. ${ }^{\text {II }}$ Although a categorical distinction between principals and accomplices is indeed achieved by this delinking, it comes at a significant cost. The issue of Brdanin's delinking is especially striking when one considers that the JCE doctrine was recognized and announced in Tadic to solve this very problem, namely link RPPs with defendants. ${ }^{\mathrm{I2}}$ For this reason, it is no surprise that Judge Cassese, who sat on the Tadic Appeals Chamber and is most associated with the development of the JCE doctrine, referred to the Brdanin Appeals Chamber decision as 'excessive' and concluded that the decision 'raises doubts about its consistency with the nullum crimen principle and the principle of personal responsibility'. ${ }^{3}$

The resulting state of the jurisprudence, post Brdanin, is best expressed in the following way. A defendant at the leadership level is a member of a horizontal

6 Ibid., para. 4I4.

7 Ibid., para. 4I3, concluding that 'the existence of this link is a matter to be assessed on a case-by-case basis' but conceding in a footnote that the Appeals Chamber 'declines at this time to address whether this equating is still appropriate where the accused is convicted via JCE for crimes committed by a principal perpetrator who was not part of the JCE, but was used by a member of the JCE'.

8 See Separate Opinion of Judge Meron in Brdanin, supra note 4, para. 6.

9 See, e.g., Prosecutor v. Popović et al., Trial Judgement, Case No. IT-05-88, T.Ch., Io June 2010, para. I029: 'It is necessary however, that the JCE member used the non-member to commit the actus reus of a crime that can be inputed [sic] to the member of the JCE'. See also Prosecutor v. Krajišnik, Appeals Judgement, Case No. IT-oo-39, A.Ch., paras. 225-226: 'Factors indicative of such a link include evidence that the JCE member explicitly or implicitly requested the non-JCE member to commit such a crime or instigated, ordered, encouraged, or otherwise availed himself of the non-JCE member to commit the crime.'

Io E. van Sliedregt, 'System Criminality at the ICTY', in A. Nollkaemper and H. van der Wilt (eds.), System Criminality in International Law (2009), I83, at I98.

I I This differential is important. See, e.g., J. D. Ohlin, 'Commentary on Stakić, the Co-Perpetrator Model of Joint Criminal Enterprise', (2008) I4 Annotated Leading Cases of International Tribunals 739, at 739-52; see also K. J. Heller, The Nuremberg Military Tribunals and the Origins of International Criminal Law (20I I), 390. See also Prosecutor v. Kvočka et al., Trial Judgement, Case No. IT-98-30/I, T.Ch., 2 November 200I, concluding that JCE doctrine should distinguish between co-perpetrators who share the intent to commit the crime and accomplices who knowingly contribute to the criminal enterprise.

I 2 See Prosecutor v. Tadić, ICTY Appeals Chamber Judgement, Case No. IT-94-I-A (I 5 July I 999), para. I 9I.

I3 See A. Cassese, International Criminal Law (2008), I95, also calling the decision 'all the more objectionable' because the Appeals Chamber noted that JCE applies to 'large-scale cases'. 
JCE with other co-perpetrators at the leadership level. The crime was physically committed by the RPP - far below - but the doctrine of JCE was not used to vertically link the horizontal JCE with the RPP. For example, Judge Meron suggested that the link could be provided by the mode of liability of 'ordering', which is explicitly listed in Article 7(I) of the Statute, ${ }^{14}$ and other natural possibilities included the concept of indirect perpetration or perpetration-by-means..$^{15}$

Another solution to the problem is to recognize the possibility of subsidiary or interlinked JCEs. ${ }^{16}$ The two ideas ought to be distinguished, because the term 'subsidiary JCE' is usually used to describe a more specific JCE that is contained within a larger, more general JCE. ${ }^{17}$ For example, a group of individuals might enter into a general JCE to engage in persecution against a particular ethnic group, thus constituting a crime against humanity. Within that JCE, there might reside a more particular JCE where individuals devise a particular system of mistreatment - say a prison camp or a confined ghetto - in order to actualize that campaign of persecution. ${ }^{18}$ The subsidiary JCE would necessarily be closer to the ground than the more general JCE, and the membership of each would not be co-extensive, though they would contain at least one common member. ${ }^{19}$ One can even imagine a tertiary JCE embedded one level further, involving the treatment of particular detainees at the camp.

An interlinked JCE is a different idea. Under this model, the doctrine of JCE is used to link the horizontal members of a JCE at the leadership level, and the doctrine is also used to vertically link one member of the leadership JCE with mid-level officers and the RPP on the ground. The JCEs intersect because they have at least one member in common, namely the indirect perpetrator at the leadership level. Under this model, all members of the leadership level would be vicariously responsible for the crimes committed by the RPP. ${ }^{20}$ As Gustafson indicates, the interlinked JCE model 'does not require the principal perpetrators to be included within the scope of a particular JCE, while, at the same time, it provides a method of tracing liability from these principal perpetrators to higher-level accuseds'. ${ }^{21}$ However, it is unclear why the argument does not also work in reverse. If the two interlinked JCEs allow a court to trace liability up to the leadership level, why do they not also trace liability back down to the RPP as well? The JCE doctrine mandates that all members of the enterprise are vicariously responsible for the actions of its members. ${ }^{22}$ If linking two

I4 See Brdanin, supra note 4, para. 6.

I5 See ibid., paras. I0-I3, expressing concern with Judge Meron's notion of ordering and also discussing perpetration through an instrument. Shahabuddeen argued that RPPs were members of the JCE because they agreed or acquiesced to it.

I6 This solution is proposed in, inter alia, K. Gustafson, "The Requirement of an "Express Agreement" for Joint Criminal Enterprise Liability: A Critique of Brđanin', (2007) 5 JICJ I34, at I47.

I7 Ibid., at I54.

I8 See, e.g., A. Strippoli, 'The Kravica Case at the Court of Bosnia and Herzegovina', (2009) 7 JICJ 577, at 589.

I9 See Gustafson, supra note I6, at I54.

20 A similar doctrine exists in conspiracy law. See, e.g., Kotteakos v. United States, (I 946) 328 US 750, at 755; United States v. Bruno, (I 939) I05 F.2 d 92 I (2 nd Cir.); United States v. Carpenter, (I 986) 79I F.2 d I024 (2 nd Cir.).

2I See Gustafson, supra note i6, at I55.

22 See, e.g., Prosecutor v. Vasiljevic, Separate and Dissenting Opinion of Judge Shahabuddeen, Appeal Judgement, Case No. IT-98-32-A, 25 February 2004, para. 31. See also Gustafson, supra note I6, at I46. 
JCEs allows vicarious responsibility across the interlink, then the argument ought to work in both directions. At this point, the result conflicts with at least one policy rationale behind the Brdanin delinking, which was to limit the liability of the RPP due to their remoteness - by removing them from the JCE. In any event, the ICTY has so far elected not to solve the Brdanin question by appealing to the notion of interlinked JCEs. ${ }^{23}$

But there is a deeper issue raised by the interlinked JCEs. Although each JCE links multiple individuals together, what justification is there for linking the JCEs together, other than the existence of one overlapping member? Why should criminal liability traverse the interlink? This is not to suggest that no justification could be offered. Rather, the point is that some justification must be made for this doctrinal move. The combination of the vertical and horizontal linking principles requires more than simply referencing the banal fact that both are JCEs, namely that the vertical and horizontal linking is performed with the same mode of liability.

For the moment, it is not so important which mode of liability is used to perform the vertical linking. The important point is that, regardless of which vertical mode of liability is used, it must be combined with the doctrine of JCE in order to successfully link the defendant to the RPP. From a purely theoretical standpoint, the following question is generated: what principle allows one to combine modes of liability together? The Brdanin Appeals Chamber neither answered nor even asked this question, but this doctrinal move is one that stands in need of justification. This is especially true given that the Appeals Chamber in Kvočka implied that such combinations of modes of liability were not permitted. ${ }^{24}$

This problem of how to combine modes of liability along vertical and horizontal axes is rarely addressed by international courts. To criminal-law lawyers trained in the United States, the question is completely novel, since the doctrine of conspiracy would generally allow courts to draw a large circle around all participants in a collective criminal endeavour (whether located on the horizontal or vertical plane) and declare all of them to be co-conspirators. ${ }^{25}$ Furthermore, the issue remained similarly unaddressed by the ICTY prior to the Brdanin delinking because the JCE doctrine allowed Trial Chambers to draw an analogous circle around all

23 Although some scholars have described the Brdanin Appeals Judgement as adopting the interlinked JCE model, this semantic characterization seems inexact. See, e.g., E. van Sliedregt, 'Modes of Participation', in L. N. Sadat (ed.), Forging a Convention for Crimes against Humanity (20I I), 243-4. The Appeals Judgement neither referred to 'interlinked' JCEs nor even suggested that the link between the leadership JCE and the RPP was established by a JCE. Instead, the Appeals Chamber majority indicated that the link was to be evaluated on a case-by-case basis, and Judge Meron suggested 'ordering' as the correct mode of liability.

24 See Prosecutor v. Kvočka et al., Appeals Judgement, Case No. IT-98-30/I, A.Ch., 28 February 2005, para. 9I: 'The Appeals Chamber emphasizes that joint criminal enterprise is simply a means of committing a crime; it is not a crime in itself. Therefore, it would be inaccurate to refer to aiding and abetting a joint criminal enterprise. The aider and abettor assists the principal perpetrator or perpetrators in committing the crime.' See also Prosecutor v. Šainović et al., Decision on Ojdanic's Motion Challenging Jurisdiction: Indirect Co-Perpetration, Case No. IT-05-87, T.Ch., 22 March 2006, para. 37.

25 For a discussion of the theoretical basis of the conspiracy doctrine, see J. D. Ohlin, 'Group Think: The Law of Conspiracy and Collective Reason', (2008) 98 Journal of Criminal Law and Criminology I47 (criticizing overexpansive nature of conspiracy liability generally and Pinkerton liability specifically). 
participants in a JCE, regardless of their proximity to the actus reus of the crime. Although Brdanin accomplished a delinking, the task of relinking was apparently left to others.

\section{INDIRECT CO-PERPETRATION AT THE ICC}

In its earliest cases, the ICC has confronted the issue of combining vertical and horizontal modes of liability. The Pre-Trial Chamber famously rejected a 'mechanical' application of the ICTY doctrine of JCE, choosing instead to apply Roxin's control theory of perpetration in the Lubanga, ${ }^{26}$ Katanga, ${ }^{27}$ and Al Bashir cases. ${ }^{28}$ The scholarly literature is replete with analysis of the ICC's use of Roxin's theories. ${ }^{29}$ However, a more searching analysis is required of the particular ad hoc combination of Roxin's theories that are used by the ICC.

\section{I. An ad hoc combination}

For example, in Katanga, the Pre-Trial Chamber combined the doctrine of coperpetration (Mittäterschaft) with the doctrine of indirect perpetration (Täter hinter dem Täter), thus creating the notion of an indirect co-perpetrator (mittelbare Mittäterschaft). ${ }^{30}$ This latest concept is a genuinely novel judicial development that has no basis in Roxin's original theory, which made no mention of an indirect co-perpetrator. ${ }^{3 \mathrm{I}}$ Furthermore, national prosecutions that have relied on Roxin's control theory of perpetration, including the Fujimori prosecution, ${ }^{32}$ the German Border Guard case, ${ }^{33}$ and the junta cases, ${ }^{34}$ did not apply the concept of indirect co-perpetration. Each applied the concept of indirect perpetration through an

26 Prosecutor v. Thomas Lubanga Dyilo, Decision on the Confirmation of the Charges, Pre-Trial Chamber I, ICC-oi/o4-oi/o6, Pt.Ch.I, 29 January 2007, para. 340.

27 Prosecutor v. Germain Katanga and Mathieu Ngudjolo Chui, Decision on Confirmation of Charges, Pre-Trial Chamber, ICC-or/04-01/07-3269, 30 September 2008, para. 484 (detailing control-over-the-crime approach).

28 Prosecutor v. Omar Hassan Ahmad Al-Bashir, Second Arrest Warrant, Pre-Trial Chamber, ICC-02/05-0I/o9, I 2 July 20 Io, para. 4.

29 See, e.g., H. Olasolo, The Criminal Responsibility of Senior Political and Military Leaders as Principals to International Crimes (2009), 265-6; F. Jessberger and J. Geneuss, 'On the Application of a Theory of Indirect Perpetration in Al Bashir: German Doctrine at The Hague?', (2008) 6 JICJ 853; J. D. Ohlin, 'Joint Intentions to Commit International Crimes', (20I I) I I CJIL 72 I, at 723; M. Osiel, 'Ascribing Individual Liability within a Bureaucracy of Murder', in A. Smeulers (ed.), Collective Violence and International Criminal Justice (2010), I I 9-22.

30 See Germain Katanga and Mathieu Ngudjolo Chui, supra note 27, para. 492: 'Rather, through a combination of individual responsibility for committing crimes through other persons together with the mutual attribution among the co-perpetrators at the senior level, a mode of liability arises which allows the Court to assess the blameworthiness of 'senior leaders' adequately.'

3 I See, e.g., C. Roxin, Täterschaft und Tatherrschaft(1963). Several scholars have described the Pre-Trial Chamber's reliance on Roxin's theory of Organisationsherrschaft as 'controversial', though usually because of the court's reliance on German Dogmatikin the place of a more traditional analysis of state practice and opinio juris. See, e.g., N. Jain, 'The Control Theory of Perpetration in International Criminal Law', (20I I) I2 CJIL I57, at I84.

32 Fujimori Judgment, CSJ, Sala Penal Especial, 7 April 2009, Exp. No. AV I 9-200I, cited in K. Ambos, 'The Fujimori Judgment: A President's Responsibility for Crimes against Humanity as Indirect Perpetrator by Virtue of an Organized Power Apparatus', (20I I) 9 JICJ I37, at I43, footnote 33.

33 German Border Case, Judgment of 26 July I 994 against Former Minister of National Defence Kessler and Others, 40 BGHSt (I995) 2 I8-40, reprinted in (20I I) 9 JICJ 2 I I (edited by G. Werle and B. Burghardt, translated by B. Cooper).

34 Juntas Trial Case, Judgment of 9 December 1985 , translation reprinted in (I987) 26 International Legal Materials 317, cited and analysed in Olasolo, supra note 29, at I27-9. 
organizational machinery of power. ${ }^{35}$ Only a few scholars have directly tackled the question of whether the ad hoc combination of these modes of liability is appropriate. ${ }^{36}$

The ICC Pre-Trial Chamber described Katanga as an indirect co-perpetrator because he controlled, on the vertical axis, a militia that followed his orders, but he also collaborated on a horizontal direction with another defendant, Chui, who provided an essential contribution to the collective effort. ${ }^{37}$ Neither indirect perpetration nor co-perpetration, by itself, was sufficient to capture the legal relationships between the relevant perpetrators because Katanga and Chui controlled separate militias, each of which committed elements of the overall criminal endeavour. However, each militia reported to its own commander, perhaps due to the fact that the militia were ethnic (or tribal) organizations that could not (or would not) be integrated into a single organization. ${ }^{38}$ One is therefore left with two parallel vertical organizations that were joined at the leadership level only by virtue of the co-operation between the co-perpetrators Katanga and Chui. ${ }^{39}$ In this case, both Katanga and Chui were indirect perpetrators of their own organizations, though only by co-operating at the leadership level could their indirect perpetration constitute the war crimes for which they were indicted. ${ }^{40}$

Katanga objected to the creation and application of this new mode of liability. ${ }^{4 \mathrm{I}}$ His argument was buttressed, in part, by the fact that an ICTY Trial Chamber had explicitly held in Milutinović that indirect co-perpetration was not an accepted mode of liability under customary international law as of $1992.4^{42}$ The Pre-Trial Chamber was left to argue that indirect co-perpetration had a statutory basis because Article 25(3)(a) of the Rome Statute included co-perpetration and indirect perpetration provisions. But, confronted with the fact that Article 25 says nothing about indirect co-perpetration, the Pre-Trial Chamber could only muster the following wisp of an argument:

The Chamber finds that there are no legal grounds for limiting the joint commission of the crime solely to cases in which the perpetrators execute a portion of the crime

This theory, Organisationsherrschaft, is one version of indirect perpetration. See C. Roxin, 'Crimes as Part of Organized Power Structures' (translated by B. Cooper), (20I I) 9 JICJ I93, reprinted from Goltdammer's Archiv fur Strafrecht (1963), I93-207; Roxin, supra note 31, at 244. See also F. C. Schroeder, Der Täter hinter dem Täter: Ein Beitrag zur Lehre von der mittelbaren Täterschaft (1965).

36 For one excellent example, see T. Weigend, 'Perpetration through an Organization: The Unexpected Career of a German Legal Concept', (2OI I) 9 JICJ 9I, at I IO-I I: 'The critical issue lies not in joining human tools but in what it means to "control" their operation.' See also Olasolo, supra note 29, at 306-30; S. Manacorda and C. Meloni, 'Indirect Perpetration versus Joint Criminal Enterprise: Concurring Approaches in the Practice of International Criminal Law?', (201 I) 9 JICJ I59, at I74: 'Whether this form of indirect co-perpetration is recognized by international criminal law remains, however, unclear.' B. Burghardt and G. Werle, 'Die mittelbare Mittäterschaft-Fortentwicklung deutscher Strafrechtsdogmatik im Volkerstrafrecht?', in R. Bloy, Gerechte Strafe und legitimes Strafrecht: Festschrift für Manfred Maiwald zum 75. Geburtstag (2010), 849-64.

37 See Germain Katanga and Mathieu Ngudjolo Chui, supra note 27, paras. 543-545.

38 Ibid., para. 493 (referring to 'ethnical loyalties within the respective organizations').

39 Ibid., para. 548.

40 Ibid., para. 555 ('coordinated essential contribution by each co-perpetrator resulting in the realisation of the objective elements of the crime').

4 I Ibid., para. 474 .

42 See Ohlin, supra note 25; Prosecutor v. Šainović et al., Decision on Ojdanic's Motion Challenging Jurisdiction: Indirect Co-Perpetration, Case No. IT-05-87, T.Ch., 22 March 2006, para. 37. 
by exercising direct control over it. Rather, through a combination of individual responsibility for committing crimes through other persons together with the mutual attribution among the co-perpetrators at the senior level, a mode of liability arises which allows the Court to assess the blameworthiness of 'senior leaders' adequately.43

This statement came right after the Pre-Trial Chamber's analysis that the text of the Statute was ambiguous and that the 'or' between the co-perpetration and indirectperpetration provisions could be read either as an 'inclusive or' or as an 'exclusive or' ${ }^{44}$ It is therefore a bit perplexing that the Pre-Trial Chamber could not conceive of a single 'legal ground' for selecting the 'exclusive or' over the 'inclusive or'. One can immediately think of an obvious possibility: in favorem vitae, libertatis, et innocentiae omnia praesumuntur.

There are several different ways in which these cases of indirect co-perpetration can be manifested. It is important to distinguish them in order to clarify the exact relationship between the horizontal and vertical elements. First, there is the situation that Katanga and Chui allegedly found themselves in: each an indirect perpetrator who co-operated at the leadership level to combine their militia organizations. Although members of both militia physically perpetrated the crimes, their vertical organization remained distinct and unco-ordinated, with the exception of the toplevel co-ordination allegedly provided by Katanga and Chui. ${ }^{45}$ A second possibility is the structure described by the Pre-Trial Chamber in the case of Al Bashir, whom they characterized as collaborating with other high-ranking Sudanese political and military leaders in "directing the branches of the "apparatus" of the State of Sudan that they led, in a coordinated manner, in order to jointly implement the common plan'. ${ }^{46}$ This could be described as a 'junta model' if it turns out that the leaders exercised their control as a group over the vertical branches, rather than exercising individual control. ${ }^{47}$

A third possibility involves a horizontal group of military and political leaders who each control a vertical branch of governmental authority, though only some of the vertical branches are engaged in the physical commission of the crimes. Both

43 See Germain Katanga and Mathieu Ngudjolo Chui, supra note 27, para. 492.

44 Ibid., para. 49I.

45 Burghardt and Werle label the Katanga and Chui scenario as 'indirect co-perpetration' (mittelbare Mittäterschaft) but distinguish it from cases of 'joint indirect perpetration' (mittelbare Täterschaft in Mittäterschaft) where the hierarchical organization is controlled by a group instead of a single person. See Burghardt and Werle, supra note 36, at 863-4. Indeed, the suggestion is helpful because it is unclear whether the same doctrine can be applied to both situations, which are conceptually distinct.

46 See Prosecutor v. Omar Hassan Ahmad Al Bashir, Decision on Prosecution's Application for a Warrant of Arrest against Omar Hassan Ahmad Al Bashir, Pre-Trial Chamber I, ICC-02/05-0I/o9, Pt.Ch., 4 March 2009, para. 2 I6.

47 Cf. Weigend, supra note 36 , at III, referring to this as a 'junta' model because 'there is one group of subordinates subject to control by a group of leaders working together'; Burghardt and Werle, supra note 36, at 864 (distinguishing group control over an organization as a distinct variant of the doctrine). From the limited nature of the Pre-Trial Chamber's description of the state of affairs in Sudan, however, it is unclear if the Al Bashir 'junta' jointly controlled all of the subordinates, or if each leader controlled his or her own bureaucracy in a manner analogous to Katanga and Chui. There is also a middle position: a president might have de jure control of all of the subordinates but leave de facto operational and bureaucratic control to other political and military leaders. 
the Stakić and Bemba cases are good examples of this third structure. ${ }^{48}$ In Stakic, the Trial Chamber concluded that the defendant had authority over the civilian authorities, while his co-perpetrators each had respective control over the civilian police and military units. Although the civilian authorities under Stakić's command did not physically perpetrate any of the crimes, the Trial Chamber concluded that the civilian police forces and military units under the direction of the other indirect co-perpetrators could not have perpetrated the crimes without the logistical support of Stakić's civilian employees. ${ }^{49}$ In Bemba, the defendant was accused of being the commander-in-chief of the Movement for the Liberation of Congo (MLC) militia and of co-perpetrating his crimes with former Central African Republic president Ange-Félix Patassé. ${ }^{\circ}$ Although Patassé also controlled a hierarchical power structure (his Presidential Security Unit), the crimes were physically committed by Bemba's troops. Therefore, Patassé stood in a position roughly analogous to that of Stakić, although it is even less clear whether Patassé's subordinates were relevant for the commission of the crimes carried out by Bemba's forces..$^{\text {I }}$

As a practical and evidentiary matter, it might be difficult to distinguish between the three scenarios. For example, determining whether the control over the vertical branches was exercised by individuals within the leadership group, or by the group as a whole, depends in part on understanding the relevant power balance between the horizontal leaders, which might remain inscrutable..$^{52}$ Furthermore, if one co-perpetrator belongs to the group but does not control his own independent hierarchical structure of power, then his liability as a co-perpetrator depends on one of two legal assessments. Either he co-exercised joint control over another's vertical organization, by virtue of the nature of the horizontal collaboration, or he is vicariously liable for the acts of the RPP simply because he co-operated the leadership level and belonged to the horizontal group that planned the criminal endeavour. Although vicarious criminal liability sounds more acceptable in the first situation (joint control), it is not clear how one draws a dividing line between joint control over a vertical organization and mere membership in a horizontal organization that includes members that have vertical structures at their disposal. What is the operative difference?

In these situations, where the defendant does not have his own vertical organization at his disposal (or members of his vertical organization do not physically perpetrate the crimes), the mode of liability resembles an inverted-L-shaped form of indirect co-perpetration. Under this scheme, the two defendants at the leadership

48 Prosecutor v. Stakić, Trial Judgement, IT-97-24, T.Ch., 3I July 2003, para. 469; and Prosecutor v. Jean-Pierre Bemba Gombo, Decision Pursuant to Article 6I(7)(a) and (b) of the Rome Statute on the Charges of the Prosecutor against Jean-Pierre Bemba Gombo, ICC-0I/05-01/08, P.T.Ch. II, I 5 June 2009, para. 370.

49 Stakić, supra note 48 , paras. $482-486$.

50 See Jean-Pierre Bemba Gombo, supra note 48, para. 373. Although the Pre-Trial Chamber continuously referred to Bemba as a co-perpetrator, their description of his control over MLC troops, as well as his co-perpetration with former CAR president Angel-Félix Patassé, suggests that he was an indirect co-perpetrator. See Olasolo, supra note 29, at 3I8. The Pre-Trial Chamber's liberal citations of the Stakić Trial Chamber judgement also support this conclusion. See Jean-Pierre Bemba Gombo, supra note 48, para. 350, footnote 44I.

5 I Patassé died in April 20 I I.

52 See H. Vest, Voelkerrechtsverbrecher verfolgen (20I I), 428 (discussing horizontal co-operation) 
level would be linked together under the doctrine of co-perpetration, but then one of the co-perpetrators (or several of them) would be linked vertically to the RPP through the doctrine of indirect perpetration. After linking the two linking principles together, a court would be able to trace a line of responsibility from the RPP not only to the indirect perpetrator who controlled them along the vertical axis, but also to the co-perpetrator at the leadership level who co-operated in some manner with the indirect perpetrator. ${ }^{53}$ The result would be an inverted-L-shaped structure that vicariously attributes responsibility for the actions on the ground to the second co-perpetrator, based on the concept of indirect co-perpetration. ${ }^{54}$ In this situation, the mode of liability of indirect co-perpetration is carrying the entire load of the argument; it demands some scrutiny from the level of criminal-law theory.

None of this is to conclusively suggest, at the outset, that the notion of indirect coperpetration is inappropriate from the standpoint of criminal-law theory, customary international law, or Article 25 of the Rome Statute. ${ }^{55}$ Rather, the point of the analysis is twofold. First, the ICC's problem of combining modes of liability is structurally identical to the ICTY's problem of linking a leadership-level JCE with the RPP, which might also produce an inverted-L-shaped mode of liability. In fact, these are two instantiations of the very same problem. In the case of a leadership-level JCE prosecuted at the ICTY, it is likely that only one member of the leadership JCE would vertically direct a criminal or military organization whose members would then physically perpetrate the war crimes. Then, the political leaders who join the JCE with the military commander are vicariously responsible for the actions of the physical perpetrators by tracing their responsibility along an inverted-L-shaped path. Second, pace the ICC Pre-Trial Chamber, the connection of horizontal and vertical modes of liability is a doctrinal move that requires at least somejustification, given that one cannot just combine, willy-nilly, any number of modes of liability at will..$^{6}$ There has to be a reason to support the combination. ${ }^{57}$

Furthermore, the stakes for any particular defendant are immense because the defendant's horizontal link to other co-perpetrators at the leadership level might be established by a mental element that is far lower than shared intent. ${ }^{8}$ Under JCE III, the link might be established by knowledge of a consequence that ought to

53 This hypothetical individual could be described as a co-perpetrator or an indirect co-perpetrator. Both descriptions are equally plausible but both are simultaneously unsatisfactory. The label 'co-perpetrator' fails to capture the fact that the vicarious liability is traced upwards along a vertical axis through indirect perpetration. Second, the label 'indirect co-perpetrator' is confusing because the defendant in this scenario does not have indirect control over any of the RPP.

54 An example of this structure would be the prosecution of Salazar Monroe in Peru for his role, at the leadership level, in crimes committed along with President Fujimori. See Corte Superior de Justicia de Lima, Primera Sala Penal Especial, Judgment of 8 April 2008, Exp. No. Av. 03-2003-I8 SPE/CSJLI, pp. 98-I Io, cited in Ambos, supra note 32 , at 153 .

55 There are numerous analyses of Art. 25(3)(a) of the Rome Statute. See, e.g., Manacorda and Meloni, supra note 36, at I67-8 ('the Rome Statute clearly shows the path to be followed').

56 In agreement, see Kvočka, supra note 24, para. 91.

57 But see E. van Sliedregt, Individual Criminal Responsibility in International Law (20I2), Chapter 4, noting that 'compound' or 'multiple' participation is permitted under some circumstances in Dutch and German criminal law when the requirements of both modes of liability are met.

58 On the significance of shared or joint intentions, see Ohlin, supra note 29, at 742 (applying Bratman's sharedintentions theory to international crimes). 
be reasonably foreseeable to the defendant, or what the ICTY has called advertent recklessness. ${ }^{59}$ Similarly, under the ICC's version of indirect co-perpetration, the relevant mental element can be satisfied with dolus eventualis (which the Chamber and some commentators have equated with advertent recklessness). ${ }^{60}$ Putting aside for the moment the issue of whether dolus eventualis or advertent recklessness are appropriate mental elements in this context, ${ }^{6 \mathrm{I}}$ it is clear that, under the current case law of the ICTY, a co-perpetrator's connection at the horizontal level might be established simply because either he was reckless as to the crimes that might be committed or he reconciled himself to that possibility. ${ }^{62}$ The earliest decisions of the ICC have been split on this issue. ${ }^{63}$ Furthermore, the ICC Pre-Trial Chamber has even applied the theory when the underlying common plan is non-criminal ${ }^{64}$ - an element that ironically far exceeds the contours of the common-law mode of liability known as conspiracy, which as a historical matter all of these doctrines were meant to supplant. ${ }^{65}$ Either way, given that the horizontal link to the indirect perpetrator is often easily established, it is imperative that the doctrine conclusively justifies the combination of the vertical and horizontal linking principles.

59 Regarding the general acceptability of dolus eventualis as a sufficient mental element, the Stakić Appeals Chamber and Trial Chamber were in complete agreement, despite the fact that the former applied indirect co-perpetration and the latter applied JCE III. In other words, both doctrines allow the application of a lower mental state that may have a greater impact on the outcome of the case than the choice of mode of liability. See Stakić, supra note 48, para. 587. However, the Trial Chamber did concede that dolus eventualis was insufficient for genocide, which requires dolus specialis - ibid., para. 530 - a conclusion that was not accepted by the Appeals Chamber in that case. See Prosecutor v. Stakić, Appeal Chamber Judgement, IT-97-24, A.Ch., 3 July 2003, para. 38 (citing Prosecutor v. Brdanin, Decision on Interlocutory Appeal, ICTY Appeals Chamber, Case No. IT-99-36-A ( I 9 March 2004), paras. 9-I0).

60 See, e.g., Stakić, supra note 59, paras. 99-I03 (equating advertent recklessness with dolus eventualis and concluding that neither violates the nullem crimen principle); Tadić, supra note I2, para. 220 (same); Cassese, supra note I3, at 20I. However, several scholars have pointed out that dolus eventualis requires a distinctive attitude regarding the outcome (approval and identification with the evil result) that is not contained in the common-law concept of recklessness. See, e.g., G. P. Fletcher and J. D. Ohlin, 'Reclaiming Fundamental Principles of Criminal Law in the Darfur Case', (2005) 3 JICJ 539, at 554. Olasolo agrees with this analysis and further concludes that the standard that the ICTY actually applies in JCE III cases is the lower requirement of recklessness based on reasonable foreseeability, not dolus eventualis. See Olasolo, supra note 29, at I75-6.

6 I Art. 30 of the Rome Statute states that the default mental element, unless otherwise specified, is intent and knowledge. Unfortunately, the Rome Statute's definition of intent - 'means to engage in the conduct' and 'means to cause that consequence or is aware that it will occur in the ordinary course of events'-is understood radically different by common-law and civil-law criminal lawyers. To common-law lawyers, this definition would be satisfied by the two mental elements - acting purposely and acting knowingly - that the Model Penal Code used to replace the ambiguous notion of acting with intent. For a discussion of the relationship between Art. 30 and dolus eventualis, see G. Werle and F. Jessberger, “Unless Otherwise Provided": Article 30 of the ICC Statute and the Mental Element of Crimes under International Criminal Law', (2005) 3 JICJ 35, at 52-3, concluding that Art. 30 excludes dolus eventualis as the default but that it might be 'otherwise provided' as an appropriate mental element in other articles of the Rome Statute or even customary international law.

62 In this regard, see Stakić, supra note 59, paras. IOI-IO3.

63 Compare Jean-Pierre Bemba Gombo, supra note 48, paras. 366-369 (concluding on the basis of travaux préparatoires that Rome Statute drafters dropped the idea of including recklessness or dolus eventualis within Art. 30's default mental element) with Thomas Lubanga Dyilo, supra note 26, paras. 352-353 (accepting dolus eventualis within Art. 30 's default rule).

64 See Jean-Pierre Bemba Gombo, supra note 48, para. 35I; Thomas Lubanga Dyilo, supra note 26, para. 344. For a discussion, see T. Weigend, 'Intent, Mistake of Law, and Co-Perpetration in the Lubanga Decision on Confirmation of Charges', (2008) 6 JICJ 47I, at 486.

65 In common law, a conspiracy is defined as an agreement between two or more individuals to commit a criminal or unlawful act. An agreement to commit a lawful act has never fallen within the ambit of the conspiracy doctrine. For a discussion, see Ohlin, supra note 25, at 152. 


\subsection{Does indirect co-perpetration require special justification?}

To put the matter in doctrinal terms, the doctrines of co-perpetration and indirect perpetration have completely separate requirements. Co-perpetration based on Roxin's theory of domination over the act requires joint control over the act, with each member providing an essential contribution, and each member's knowledge of the objective circumstances giving rise to this joint control. ${ }^{66}$ By contrast, indirect perpetration based on Roxin's theory requires either that the defendant use a subordinate individual who is deployed as an instrument to commit the crime or the defendant has authority over a hierarchical and rule-governed organization whose members, any one of whom is replaceable, carry out the crimes under the hegemony of the leader. ${ }^{67}$ The normative justification for the vicarious liability is different in each case. Although both are based on underlying principles of hegemony over the act (Täterschaft), one requires co-ordinated behaviour based on a joint intention (excepting dolus eventualis), while the other requires something quite different: imposing one's will upon another individual or upon an organization that one controls. In such a case, the physical perpetrator's will is either completely eviscerated or at the very least subordinated to the will of the indirect perpetrator (Hintermann). ${ }^{68}$ In contrast, co-perpetration involves co-operative activity. ${ }^{69}$ These are quite different phenomena, each of which bears its own moral rationale for criminal liability. ${ }^{70}$

So, one might object that no special or additional justification is required for combining indirect perpetration and co-perpetration. Indeed, courts have occasionally claimed that applying indirect co-perpetration requires that the prosecution demonstrate that the requirements of both modes of liability have been met. This boils down to finding that the defendant was a co-perpetrator by virtue of his joint control over the crime and was an indirect perpetrator by virtue of his use of a vertical organization. In theory, this objection is sound but, in practice, the ICC has not followed these requirements. In Katanga and Chui, the ICC Pre-Trial Chamber (PTC) suggested that each defendant could be held responsible for the totality of the conduct performed by both vertical organizations - which, when combined, constitute an international crime. This implies that Katanga can be held vicariously liable for the actions of Chui's vertical organization, and Chui can be held vicariously liable for Katanga's vertical organization. However, the court also suggested that each defendant only had direct control over his or her own vertical organization. It is therefore not the case that both Katanga and Chui each satisfied the demands of the indirect-perpetration doctrine.

66 See, e.g., Roxin, supra note 3I, at x; G. P. Fletcher, Rethinking Criminal Law (2000), 655-7; Thomas Lubanga Dyilo, supra note 26, paras. 330-332; Olasolo, supra note 29, at 36 (discussing Roxin and his predecessor, Welzel).

67 See Roxin, supra note 35, at 200-I; Ambos, supra note 32, at I49-50; Olasolo, supra note 29, at II6-I8; G. Werle, Principles of International Criminal Law (2009), I 78-80.

68 Scholars disagree over whether a conviction for indirect perpetration requires that the physical perpetrator have his culpability negated due to his lack of autonomy. Roxin argued that Organisationsherrschaftconstituted an exception to this rule, known as the autonomy principle, because indirect perpetration was not limited to cases in which the physical perpetrator was mistaken or coerced. See Roxin, supra note 35, at I96-7; Olasolo, supra note 29, at I I 7; Ambos supra note 32, at I 48; Schroeder, supra note 35. The Rome Statute has definitively rejected the autonomy principle requirement in Art. 25(3)(a).

69 See, generally, G. P. Fletcher, 'New Court, Old Dogmatik', (2OI I) 9 JICJ 179.

70 See Ambos, supra note 32, at 153. 
The application of indirect co-perpetration by the Trial Chamber in Stakić represents another innovative application of the doctrine where the defendant does not have control over the vertical organization whose members physically perpetrate the crimes. This further suggests that the doctrine cannot simply be justified by the fact that the requirements for both sub-doctrines are established for each defendant. Stakić, as a municipal official, was in control of his local civilian bureaucracy, which the court found was required for logistical support of the other vertical branches that physically perpetrated the crimes. But the members of the civilian bureaucracy did not physically perpetrate any of the crimes - the other vertical organizations did that. It is therefore not the case that Stakić personally met the requirements for both indirect and co-perpetration.

In each case, if the respective court had required fulfilment of all requirements of each doctrine, then cross-vicarious liability for acts performed by each other's vertical organizations could only be justified by joint control over both organizations, which the court said did not exist in this case. However, none of this suggests that indirect co-perpetration is fundamentally unsupportable. Rather, it simply suggests that the new hybrid doctrine requires its own justification, since, in reality, the doctrine exceeds the reach of what co-perpetration and indirect perpetration can accomplish independently of each other. Specifically, if the ICC can apply indirect coperpetration to cases in which the defendant does not share control over the vertical organization that physically perpetrates the crimes, then there is no shortage of geometrical possibilities, including an inverted-L-shaped structure of vicarious liability.

The ICC's recent Pre-Trial judgments in the Kenyan case represent another innovative geometrical possibility for indirect co-perpetration. ${ }^{7 \mathrm{I}}$ In Muthaura et al., the Chamber held that crimes against humanity were committed by members of the Mungiki, a 'hierarchical and organized apparatus of power'. However, the PTC was inconsistent in its statements about who controlled the vertical operation. The PTC first stated that Njenga 'possessed exclusive control' over the organization, ${ }^{72}$ but then later contradicted this statement by concluding that control was transferred to Muthaura and Kenyatta, even though 'Njenga continued to act as the Mungiki top leader while in detention'. ${ }^{73}$ Once again, this appears to be another case in which the relationship between the co-perpetrators and their 'control' over the vertical organization in question remains utterly obscure. How did Njenga manage to retain control over the Mungiki while in detention if he transferred ultimate control of the organization to Kenyatta and Muthaura? Either Njenga exercised exclusive control or he did not. If he did, then Kenyatta and Muthaura did not independently meet the standards for indirect perpetration. It is therefore false to suggest that the ICC only applies indirect co-perpetration in cases in which all of the requirements of each underlying mode of liability are established.

7I See Prosecutor v. Francis Kirimi Muthaura and Uhuru Muigai Kenyatta, Decision on Confirmation of Charges, ICC-oi/og-02/I I, P.T.Ch. II, 23 January 2012.

72 Ibid., paras. I90, 36I.

73 Ibid., para. 368 . 


\section{THE PERSONALiTy PRINCIPLE}

The question then becomes: what type of argument can be marshalled to justify the combination of a horizontal linking principle with a vertical linking principle? In this section, I suggest that the missing element in such an argument can only be provided by a second-order linking principle. The principle is 'second-order' because it is a linking principle that itself links two other linking principles (the modes of liability) and therefore represents a higher-order or meta-level linking principle. ${ }^{74}$ Without such an implicit second-order linking principle, there would be no reason to allow the linking of the first-order linking principles.

First, an objection: the second-order linking principle is unnecessary because we need a convincing account of co-perpetration, nothing more. In this vein, a convincing account of co-perpetration would explain the nature of horizontal cooperation and also provide a normative justification for the attribution of liability to each co-conspirator. Is that not the point of having a co-perpetration doctrine in the first place?

To answer this objection, it is important to distinguish the nature of the attribution in cases of indirect co-perpetration. These cases do more than simply vicariously attribute the acts of co-perpetrators to the defendant. That is what happens in cases of garden-variety co-perpetration. But cases of indirect co-perpetration involve a form of double vicarious attribution. The act of the RPP is first vicariously attributed to the indirect perpetrator and then, as a second step, the indirect perpetrator's vicarious liability is attributed to the other co-perpetrators. In a sense, it is inaccurate to say that the other co-perpetrators are held vicariously liable for the criminal acts of the indirect perpetrator - because the relevant crimes are actually committed by the members of the hierarchical organization, not by the indirect perpetrator. The more precise formulation is that the indirect perpetrator's vicarious responsibility is attributed, in a form of double vicarious responsibility, to his other co-perpetrators residing at the horizontal level. This is more than just a case of co-perpetration, because co-perpetration only provides a normative justification for vicarious responsibility of the criminal acts committed by co-perpetrators. In other words, in cases of indirect co-perpetration, the other co-perpetrator has not performed the relevant crime. So the doctrine does more than just combine a mode of liability with a substantive crime - it combines one mode of liability with another mode of liability and then with a substantive crime. This brings us back to the present inquiry, namely that some second-order linking principle must justify the linkage of the modes of liability.

What would this second-order linking principle look like? In the present section, I argue that the second-order linking principle must emphasize the collective nature of the horizontal group - what I call the personality principle. In theory, there are other principles that could be described as second-order principles, but none of them

74 The phrase 'second-order' has been used in many other theoretical contexts, although not within the scholarly literature on JCE or indirect co-perpetration. For a famous example, see H. G. Frankfurt, 'Freedom of the Will and the Concept of the Person', (I 97 I) 68 Journal of Philosophy 5, at 8-10 (distinguishing second-order desires from first-order desires). 
provides a normative reason to support the vicarious liability of acts committed along the vertical axis. ${ }^{75}$

The most plausible candidate for a second-order linking principle is based on the notion of personality. ${ }^{76}$ Under this principle, the co-perpetrators at the leadership level constitute a joint agent, such that the indirect perpetration by one leader is directly attributable to the collective agent that is devoted to a particular criminal goal. ${ }^{77}$ One could refer to this collective agent as a legal person, a group agent, or an organization, though there is nothing essential about these terminological choices. ${ }^{78}$ Suffice it to say that the horizontal leaders function as a collective, and leave the nature of that collective to the side for the moment. The term 'personality principle' is meant to capture that collective nature and nothing more.

There are strong reasons for preferring the personality principle as the relevant second-order linking principle. By analogy, much of Roxin's control theory is based on the notion that the relevant unit is the organized power apparatus that the indirect perpetrator uses to commit the crime. ${ }^{79}$ The notion of Organisationsherrschaft implies, obviously, a kind of collective entity. ${ }^{80}$ Other German scholars, such as Dencker, have gone even further and suggested that the organization itself is the primary and irreducible organ for the purposes of attributing the criminal action and the resulting liability. ${ }^{8 \mathrm{I}}$ Indeed, one way of interpreting my thesis is that something resembling Dencker's Zurechnungsprinzip Gesamttat (collective imputation principle), or what I have more generally described as a personality principle, is implicitly but necessarily relied upon as a second-order linking principle in cases of combined vertical-horizontal group liability such as indirect co-perpetration (or leadership-level JCE combined with a vertical mode of liability). ${ }^{82}$

Of course, the issue is what the general principle will look like and how it relates to the more specific criminal-law doctrines. Ambos has argued that the models ought

75 One might, for example, appeal to the principle of transitivity. But with regard to modes of liability generally, it cannot be the case that the principle of transitivity always applies. Assume that A aids B in his criminal endeavour. $\mathrm{B}$ then aids $\mathrm{C}$ in his criminal endeavour. Does that fact alone make $\mathrm{A}$ an accomplice to the crimes of $\mathrm{C}$ ? With no additional facts added, A would not be an accomplice to C. Liability would only attach if it could be shown that A's assistance to B was, in some way, also assistance to C's endeavour. In the absence of such a fact, A remains derivatively liable for B's crime, B remains derivatively liable for C's crimes, but A is not derivatively liable for C's crimes.

76 See, generally, A. Eser and F. Rettenmaier, 'Criminality of Organizations: Lessons from Domestic Law: A Comparative Perspective', in A. Nollkaemper and H. van der Wilt (eds.), System Criminality in International Law (2009), 222.

77 Dencker's Zurechnungsprinzip Gesamttat (collective imputation principle) gestures in this direction as well. See F. Dencker, Kausalität und Gesamttat (I996), arguing that the criminal enterprise constitutes the central object of attribution. Indeed, one way of interpreting my thesis is that something resembling Dencker's Zurechnungsprinzip Gesamttat (collective imputation principle), or what I have more generally described as a personality principle, is implicitly but necessarily relied upon as a second-order linking principle in cases of combined vertical-horizontal group liability such as indirect co-perpetration or leadership JCE combined with a vertical mode of liability.

78 In another context, see also C. List and P. Pettit, Group Agency: The Possibility, Design, and Status of Corporate Agents (20I I), I57.

79 See Roxin, supra note $3 \mathrm{I}$, at 249.

80 Ibid., at 246.

8I See Dencker, supra note 77. Although Dencker's theories have not been applied by international courts, Kai Ambos has made extensive reference to them in his work. See, e.g., K. Ambos, 'Joint Criminal Enterprise and Command Responsibility', (2007) 5 JICJ I59, at I68.

Dencker, supra note 77 . 
to be separated so that one doctrine deals with the collective accountability of the organization and another doctrine deals with individual responsibility, though, in truth, neither is mutually exclusive. ${ }^{83}$ The issue of exclusivity is paramount here, because critics often worry that theories of collective liability will obfuscate the individual's personal culpability, either by inflating it through guilt by association or by deflating it through mitigation. ${ }^{84}$ But, as the foregoing analysis demonstrates, recognition of the collectivist impulse behind indirect co-perpetration is essential if we are to zealously guard the principle of individual culpability.

In essence, the personality principle, like Dencker's collective imputation principle, is the deeper and more abstract principle that resides behind the more specific criminal-law doctrines that are being applied by international courts. It is already commonplace for scholars to recognize the collective nature of Roxin's theories along the vertical axis. However, the relevant collective entity for the purposes of Organisationsherrschaft resides along the vertical axis, namely the hierarchical organization that exhibits rule-governed processes. ${ }^{85}$ In the case of combined horizontal-vertical liability, though, the group entity in question is a leadership enterprise along the horizontal axis. ${ }^{86}$ This article is simply a plea to recognize the importance of the principle that is operating along the horizontal axis.

Might we extend the metaphor of personality or collectivism that is implied in Organisationsherrschaft and then simply apply it to the horizontal context at the leadership level? There might be strong factual arguments to support this extension. First, members of a leadership-level JCE are dedicated to a particular criminal goal. They often deliberate and engage in collective decision-making by gathering relevant evidence, deliberating in common, and selecting a course of action. The decisionmaking might be pursued democratically, or not. Regardless, though, the members of a leadership JCE not only co-ordinate their actions, they also co-ordinate their reasons to such a degree that they might be considered a group agent, a legal person, a collective.

Nothing hinges on whether you call the leadership-level JCE - the co-perpetrators - a legal person, a group agent, an enterprise, or even a conspiracy. The real issue here is whether some aspect of the collective nature of the group at the top of the hierarchy is sufficiently robust that it justifies treating the collectivity as the

83 K. Ambos, 'Zur “Organisation” bei der Organisationsherrschaft', in M. Heinrich, C. Jäger, and B. Schünemann (eds.), Festschrift für Claus Roxin zum 80. Geburtstag am I5. Mai 20 I I (20I I), 852.

84 Compare G. P. Fletcher and J. D. Ohlin, Defending Humanity (2008), I 86-7, with J. McMahan, 'Collective Crime and Collective Punishment', Criminal Justice Ethics (2008), 9. Collective mitigation means that the individual's participation in the collective effort provides a reason to reduce the culpability, and perhaps punishment, of the individual, since the culpability is shared among a larger group of individuals. Several scholars, including McMahan, are sceptical of collectivist theories because they might imply fallacious results like precisely this kind of mitigation.

85 See, e.g., Ambos, supra note 32, at I48 ('Be that as it may, the traditional system of individual responsibility, as applied for ordinary criminality characterized by the individual commission of single crimes, must be adapted to the needs of international criminal law aiming at the development of a mixed system of individualcollective responsibility in which the criminal enterprise or an organization as a whole serves as the entity upon which attribution of criminal responsibility is based'). However, the collective entity to which Ambos refers is the vertical organization.

86 See Burghardt and Werle, supra note 36, at 863 (recognizing the existence of a corporate entity in cases of joint indirect perpetration). 
relevant unit of attribution, such that the vertical axis - the indirect perpetration can be attributed not just to the individual in control of the vertical organization, but to the entire horizontal collective. Might the personality principle provide this justification?

There are strong prudential reasons for supporting this view. It would be odd if a co-ordinated division of labour on the horizontal axis (with one member's taking responsibility for control of the vertical axis) should immunize the non-indirect perpetrators from vicarious responsibility for the acts of the physical perpetrators. As a matter of policy, adopting such a view might encourage political leaders to encourage horizontal division of labour in this manner so as to preserve plausible deniability on their part. ${ }^{87}$ The result might be more - rather than fewer - war crimes and atrocities committed using the inverted-L-shaped structure. For some international jurists, this observation alone might be sufficient to justify the use of indirect co-perpetration as a mode of liability.

On the contrary, though, it is imperative that we justify the mode of liability on theoretical and normative grounds, in addition to policy-oriented consequentialist grounds. The personality principle implies that the collective nature of the horizontal leadership - including its rational integration, meshing of sub-plans, and joint intentions - provides a reason for attributing the indirect control to all members of the group. Again, acceptance of the principle does not require positing legal personality for the horizontal group; such a result would be resisted by lawyers who are suspicious of the concept of legal personhood for corporate bodies. ${ }^{88}$ The personality principle simply requires that we take the collective nature of the horizontal group seriously enough such that we can legally conclude that the horizontal group as a whole directs the vertical axis, even if, as a factual matter, the indirect control is exercised by one constituent part (i.e., member) of the leadership collective. Other scholars have started to gesture in this direction as well. ${ }^{89}$

This provides a plausible roadmap for justifying horizontal-vertical liability in some instances. Consider, for example, the Pre-Trial Chamber's conclusion in Katanga that an:

individual who has no control over the person through whom the crime would be committed cannot be said to commit the crime by means of that other person. However, if he acts jointly with another individual - who controls the person used as an instrument - these crimes can be attributed to him on the basis of mutual attribution..$^{\circ}$

The notion of mutual attribution to the entire leadership level is theoretically plausible (and normatively defensible) if the leadership level is understood as a collective. The personality principle provides a much-needed, second-order linking principle here that acts as a foundation for the substantive doctrine to operate.

87 See Vest, supra note 52 , at 428 .

88 Cf. F. K. von Savigny, System des heutigen römischen Rechts (1840), 283.

89 See Vest, supra note 52, at 428, citing G. Heine, Taeterschaft und Teilnahme in staatlichen Matchapparaten (2000), 920. Vest suggests that leadership-level defendants should be convicted as 'system-functional co-perpetrators' of a common criminal endeavour, regardless of whether that endeavour is characterized as an instance of JCE I or co-perpetration.

90 See Germain Katanga and Mathieu Ngudjolo Chui, supra note 27, para. 493. 
Without it, the mutual attribution is downright mysterious. Recall again that this is a case of double vicarious liability, and that simply appealing to co-perpetration will not justify the double vicarious liability of these situations.

If the personality principle is the guiding force behind this new form of combined horizontal-vertical liability, there are important doctrinal consequences to consider. Liability is appropriate in cases in which each leadership-level co-perpetrator maintains his own hierarchical organization that physically perpetrates the crimes. Liability is also appropriate in cases in which a corporate entity or a junta directs the vertical hierarchical organization. However, principal liability would be inappropriate in cases in which the individuals at the leadership level do not rise to the level of a collective entity - at least not for the individuals who do not control their own hierarchical organization..$^{9 \mathrm{I}}$ For example, cases that involve a simple overlapping of interlinked JCEs - and nothing more - would not meet this criterion. In this situation, the second-order linking principle would be lacking.

The question is how one distinguishes between, on the one hand, bona fide cases of corporate action and, on the other, a mere aggregation of individuals. ${ }^{92}$ The doctrine as it is currently applied in the international case law does not provide a standard with which to answer this question..$^{93}$ Although some ideas might be borrowed from the doctrine of Organisationsherrschaft, it is important to remember that Roxin's theory was tailor-made for vertical organizational relationships and cannot be mechanically applied to the horizontal axis. For example, vertical organizations are characterized, according to Roxin, by each individual member's fungibility; if one member of the hierarchy departs or refuses to complete his task, another one takes his place as a matter of course. ${ }^{94}$ In contrast, horizontal partnerships, which Roxin analyses as cases of co-perpetration simpliciter, are characterized according to the ICC by the exact opposite: each perpetrator is essential to the task's completion and their withdrawal would frustrate the plan's success. ${ }^{95}$ Vertical and horizontal organizations are fundamentally different. ${ }^{96}$

This last point suggests an objection. Is the control theory of perpetration sufficient by itself to provide an account of the horizontal organization? ${ }^{97}$ Under this view, the horizontal organization is a case of co-perpetration pure and simple, as the ICC analysed in its most recent cases. However, co-perpetration leaves many fundamental questions unanswered with regard to joint control over a vertical

9I It is important to note that the issue at hand is not whether the defendant could be convicted simpliciter, but whether the defendant could be convicted as a principal. No one doubts that, in the situation just described, the individual at the leadership level would be guilty, at the very least, as an accomplice.

92 See G. P. Fletcher, 'Strafrecht ohne Straftäter', in Heinrich, Jäger, and Schünemann, supra note 83, at 793.

93 Ibid., at 797-8.

94 C. Roxin, 'Organisationsherrschaft und Tatentschlossenheit', Zeitschrift für internationale Strafrechtsdogmatik (2006), 296 (discussing Fungibilitätskriterium); see also Ambos, supra note 32, at I 54-5 (distinguishing between negative and positive interchangeability); Weigend, supra note 64, at 97 (discussing fungibility).

95 See Thomas Lubanga Dyilo, supra note 26, para. 346 (essential contribution as an objective element of coperpetration). For analysis, see Weigend, supra note 64, at 480 (describing the ICC's position of an 'essential' contribution as an intermediate position between 'promoting' and 'necessary' contribution).

96 Cf. Ambos, supra note 32, at I53 (discussing 'structural difference between vertical indirect perpetration and horizontal co-perpetration').

97 Cf. M. Bohlander, Principles of German Criminal Law (2009), I6I (Mittäterschaft as analogous to enterprise liability). 
organization, as this article has previously identified. These questions include, inter alia, what it means for several individuals to exercise joint control over a vertical organization that reports to one commander. The control theory and, by extension, co-perpetration do not directly answer this question, in part because neither takes seriously the horizontal organization itself as the primary unit of action and responsibility. This blind spot is all the more curious given the obsession with organizational dynamics inherent in Organisationsherrschaft. Therefore, this article argues that a deeper principle regarding the horizontal collective - what I call the personality principle - is doing at least part of the justificatory work in combining vertical and horizontal modes of liability.

\section{I. The incompleteness of joint control as an answer}

The ICC has repeatedly invoked Roxin's control theory as the basis for its interpretation of co-perpetration under Article 25(3)(a) of the Rome Statute. ${ }^{98}$ However, the control theory - by itself - cannot answer the question of why the attribution of indirect perpetration liability is appropriate to all members of the horizontal collective.

First, if one takes Roxin's theory as a starting point, the question is about joint control or hegemony over the act. ${ }^{99}$ If ultimate decision-making authority rests with one individual in a leadership group, then he exercises the hegemony; he decides whether the hierarchical organization will physically perpetrate the crimes; he follows or disregards the advice of his lieutenants; he overrules their operational micro-decisions when he considers them ill-advised. Under these criteria, the leadership group lacks personality in the relevant sense because ultimate control rests with an individual, not the group. Consequently, the other members of the leadership group are really just mid-level subordinates residing one level below the true Hintermann. ${ }^{100}$ The irony here is that, under this view, even Eichmann - the inspiration for Roxin's theory - would not have qualified as having ultimate control, since his decisions were subject to overrule by the Führer and he was replaceable if he stepped aside. ${ }^{\text {IOI }}$

Most of the cases that have already applied vertical-horizontal liability, either at the ICTY or at the ICC, have asserted that the leaders exercised joint control

\footnotetext{
98 See, most recently, Prosecutor v. Thomas Lubanga Dyilo, Trial Chamber Judgement, ICC-or/o4-01/o6, T.Ch. I, I4 March 2012, para. 994.

99 Fletcher, supra note 69 , at 190.

I00 Cf. Ambos, supra note 32, at I5I (noting that the Israel Supreme Court applied indirect perpetration below the leadership level).

Ior Compare Roxin, supra note 35, at I99-20I, with K. Ambos, 'Command Responsibility and Organisations herrschaft: Ways of Attributing International Crimes to the "Most Responsible"', in A. Nollkaemper and H. van der Wilt (eds.), System Criminality in International Law (2009), I 27, at I 52-3 (expressing scepticism about Eichmann as an indirect perpetrator). The ICC Pre-Trial Chamber, as well as the ICTY Trial Chamber in Stakić, has concluded that a defendant's contributions are indispensable if he could have frustrated the common plan by alerting the authorities. See Stakić, supra note 48, para. 490. This reasoning is fallacious because any accomplice, or third parties with knowledge of a criminal plot, could alert the authorities and potentially stop the plan from unfolding. This does not make an individual's contribution indispensable on pain of a reductio ad absurdum. If everyone is indispensable, then no one is. The same issue arises with irreplaceability; even direct perpetrators can be deemed irreplaceable if there is no time to replace them when they refuse to fire their weapons. See Ambos, supra note 32, at I 55.
} 
over the vertical organization, thus suggesting that both co-perpetrators are directly linked to the vertical organization. This legal outcome rests heavily on the notion of joint control and it is still unclear what it means for two or more individuals to 'jointly' control a vertical organization. The recent cases that have applied the concept of joint control have offered only conclusory and perfunctory analyses of the phenomenon.

For example, in Stakić, the ICTY Trial Chamber defined joint control as a case in which two or more individuals act together and one of them could frustrate the plan by refusing to do his part. ${ }^{\mathrm{I02}}$ In applying this standard to joint control over crimes committed by lower-level perpetrators, though, the Trial Chamber could only muster a few short sentences, and none of them really addressed the issue of joint control. ${ }^{\mathrm{I03}}$ Rather, the Trial Chamber stated that the crimes could not have been committed without the assistance of the government bureaucracy controlled by Stakić, and that he could have frustrated the plan by withdrawing or reporting the crimes. ${ }^{104}$ This only establishes that Stakić's contribution was a sine qua non, not that he exercised joint control over the vertical hierarchy that physically perpetrated the crimes. The point about reporting is fallacious because there was no office or official to which Stakić could have reported the crimes. In Al Bashir, the Pre-Trial Chamber analysed the president's joint control in contradictory terms. The PTC asserted that Al Bashir exercised joint control, with other high-ranking government and military leaders, over members of the counterinsurgency forces, including the Sudanese Armed Forces, the Janjaweed Militia, the Sudanese Police Forces, and other groups. ${ }^{105}$ At the same time, however, the PTC concluded that the president exercised 'full control' over the forces - a finding that substantially impairs the notion of a junta composed of multiple indirect co-perpetrators. ${ }^{106}$ The very same tension shows up in the Kenya case as well, with the court at one moment saying that Njenga had exclusive control and at another moment claiming that this control had been transferred to two others; in neither situation was the joint control sufficiently explained. ${ }^{107}$

Of particular concern is the relative importance of two phenomena: deliberation and decision-making. In some groups, individuals deliberate in common but only one individual makes the decision. This includes, for example, a president surrounded by a cabinet of advisers, or a mob boss supported by loyal lieutenants. Although the group engages in collective deliberation, the ultimate authority to make decisions - to control the vertical organization and its subordinates - rests

\footnotetext{
I02 See Stakić, supra note 48, para. 440 (quoting Roxin).

I03 Ibid., para. 490.

I04 Ibid., paras. 490-49I.

I05 See Omar Hassan Ahmad Al Bashir, supra note 46, paras. 2 I6-223. For a discussion, see Osiel, supra note 29, at 123 (noting disagreement over whether Bashir exercised total control). See also Vest, supra note 52, at 428 (uncertainty over Bashir's full control).

Io6 Judge Anita Ušacka dissented for this very reason, noting that 'I do not find any evidence which addresses the issue of the locus of control; it is unclear whether such control indeed rested fully with Omar Al Bashir, or whether it was shared by others such that each person had the power to frustrate the commission of the crime'. See Partly Dissenting Opinion of Judge Ušacka, para. IO4 (rejecting indirect co-perpetration as a proper basis for the warrant).

I07 See Francis Kirimi Muthaura and Uhuru Muigai Kenyatta, supra note 7 I, para. I86.
}

\section{CAMBRIDGE JDURNALS}


with one individual. On the other hand, some groups collectivize both deliberation and decision-making, such that the group represents a true junta model. No one individual has ultimate authority to make final decisions. This organizational structure is rare because it is notoriously unstable. ${ }^{\text {108 }}$ A true junta is likely to collapse because no one individual has authority to overrule bickering generals. Are both types of group legitimate targets for the application of indirect co-perpetration? ${ }^{\text {Iog }}$

If joint control means that each individual has, by himself, the power to direct the activities of the organization, then the notion of indirect co-perpetration is irrelevant, since both individuals are redundant indirect perpetrators. If joint control means that neither individual has the sole authority to issue directives to the organization and that both individuals must approve the directives, then very few factual situations would ever qualify for this level of joint control. ${ }^{\text {IIO }}$ Such a scenario would only exist in cases of a genuine co-presidency and, even then, each president usually has some individual authority that does not require the consent of his co-president. Finally, joint control might mean that both individuals belong to a collective body that issues the decisions by virtue of some internal voting mechanism, which is then relayed downwards by the military commander who belongs to the collective

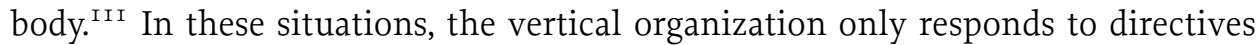
that are lawfully issued in the name of the horizontal group and discards ultra vires directives that violate the decision procedure of the horizontal group. The case for liability in this final situation largely depends on the corporate nature of the horizontal collective.

None of this suggests that the control theory of perpetration is erroneous. Rather, the preceding analysis simply demonstrates that the control theory, by itself, cannot provide a rationale for combining vertical and horizontal modes of liability in the manner in which the ICC has recently done. There is a missing link to the argument - a deeper principle that lays the foundation for the connection between the horizontal and vertical modes of liability. For convenience, I have called it the personality principle.

I08 A point Hobbes made quite famously in Leviathan, where he asserted that corporate bodies were always subject to internal division while monarchs were not. See T. Hobbes, Leviathan (I994), I I 5-I6.

I09 It is imperative to recognize the correct structure of this argument. The task is not to determine on metaphysical grounds that the entity qualifies as a group agent and then mechanically draw moral or legal conclusions from this analysis. Such an analysis would afford far too much significance to metaphysical concepts of personality or group agency. See J. D. Ohlin, 'Is the Concept of the Person Necessary for Human Rights?', (2005) I05 Columbia Law Review 209, at 238-40. Rather, the task is to determine, at the outset, the moral and legal significance of various forms of group action so as to make sensible conclusions regarding vicarious liability for the acts of the RPP.

I Io This could be described as a 'turn-your-key' model of joint control, in the sense that both marine officers on board a nuclear submarine must simultaneously turn their respective keys in order to launch a nuclear weapon. This creates the imagined scenario, often hypothesized, in which one compliant officer would need to threaten his recalcitrant colleague with a gun in order to get him to turn his key and co-launch a nuclear retaliatory strike.

I I What if the relevant voting procedure is collective consultation and advice-giving followed by autocratic decision-making by the president? This sounds more like a sole executive than a junta, yet the scholarly consensus is that the Bashircase involves a junta, even though he retained executive control over the country. The difference is relevant when one considers the liability of the other members of the alleged 'junta'. 


\subsection{The incompleteness of alternate models of co-perpetration}

One might object that the justification could be provided by an alternate account of co-perpetration. In the past, I have argued that switching back to a subjectivist theory could alleviate some of the problems associated with the control theory. ${ }^{\text {II }}$ A subjectivist approach would concentrate on the mental states of the participants, including their joint intention to commit the crime. ${ }^{\text {II3 }}$ Might the joint-intentions theory provide a basis, without any deeper principle, for indirect co-perpetration? If this were the case, it would demonstrate that the control theory is wrong but it would not necessarily imply the need for a second-order linking principle.

If one adopts this subjectivist approach, the relevant question is whether the members of the group exhibit a joint or shared intention that the hierarchical organization be used to physically perpetrate the crimes. ${ }^{\text {II }}$ Although Roxin's socalled 'functional objective' approach was meant as an antidote to the long-standing pendulum swing between formal-objective and subjective approaches, there is much to recommend a general subjective orientation, notwithstanding the wellknown costs associated with this approach. ${ }^{\text {II }}$ Joint or shared intentions are the mental building blocks of co-operative activity. ${ }^{\text {II }}$ Once individuals form a joint intention, they can formulate an overall plan, make decisions regarding strategy, and then engage in the necessary predicate actions to bring the plan to fruition, which may include farming out the physical perpetration to a vertical organization. ${ }^{\text {II }}$ Under this approach, the contours of vicarious liability at the horizontal level are determined by which individuals share the joint intention to have the vertical organization physically perpetrate the crimes. ${ }^{\text {II } 8}$ The warrant for supporting this view is that all individuals with the joint intention exhibit a culpable mental state.

The joint-intentions theory is based, in part, on Bratman's theory of joint cooperative activity. ${ }^{\text {II }}$ Although there are several different formulations, the basic building blocks of Bratman's shared-intention thesis can be reduced to the following formula. We intend to J (joint activity) if and only if:

(I) (a) I intend that we J and (b) you intend that we J.

(2) I intend that we J in accordance with and because of (I)(a), (I)(b), and meshing subplans of (I)(a) and (I)(b); you intend that we J in accordance with and because of (I)(a), (I)(b), and meshing subplans of (I)(a) and (I)(b).

\footnotetext{
I 2 See Ohlin, supra note 29 , at 747.

II 3 Ibid., at 742 .

I 4 This view is presented in ibid., at $735 \mathrm{ff}$.

I 5 For problems with the subjective approach, see Weigend, supra note 64, at 480 (noting the possibility of manipulation); Fletcher, supra note 66, at 657-8 (discussing Stashchynsky); Thomas Lubanga Dyilo, supra note 26, para. 329. However, the Model Penal Code generally takes a subjective approach that is more closely attuned with culpable mental states; see, e.g., MPC $\S$ 5.0I, and Weigend notes that German courts in practice have traditionally favoured a subjective approach.

I 6 See, generally, M. E. Bratman, Faces of Intention: Selected Essays on Intention and Agency (1999), 93- 29.

I 7 Ibid., at I 25 .

I 8 Cf. Ohlin, supra note 29, at 744.

I 9 See Bratman, supra note i I6, at I I5.
} 
(3) (I) and (2) are common knowledge between us. ${ }^{\text {I20 }}$

Bratman's theory provides a model for co-operative activity based on the unique intentional structure demonstrated by the underlying commitments that are necessary to bring these plans to fruition. Participants in these joint activities participate in such endeavours because the participants share an intention that the individuals work together to produce the desired result; often this process requires co-ordination, division of labour, and what Bratman calls 'the meshing of subplans', or, in more colloquial terms, the manner in which the joint activity will be executed. ${ }^{\mathrm{I} 2 \mathrm{I}}$

The joint-intentions theory clearly provides a subjectivist gloss on co-perpetration that is deeply compelling. Co-perpetrators of international crimes are vicariously liable for the crimes committed by their co-perpetrators if and only if the coperpetrators shared a joint intention that one of them commit the crime in question. If one of the co-perpetrators extends beyond the criminal plan and commits a rogue action, the other co-perpetrators are not liable because the participants do not share a joint intention to commit the wayward crime. ${ }^{\mathrm{I} 22}$

But the question is whether the joint-intentions theory is sufficiently robust to ground the types of indirect co-perpetration applied by the ICC. Once again, though, it is clear that a doctrinal account of co-perpetration is, by itself, insufficient to justify the attribution of the vertical mode of liability to all members of the horizontal axis. Like the control theory, the joint-intentions theory provides a similarly incomplete justification for the attribution of a vertical mode of liability to a horizontal collective.

As a final point, joint control and joint intentions do not exhaust the possible models for co-perpetration - there are other possible models. For example, one could develop a theory of co-perpetration that is based on the rational relationships between the members of the group and emphasizes the role of deliberation in the formation of collective plans. Specifically, this 'collective-reason' approach would emphasize the rational relationship between the members of the horizontal group. Under this view, a group of individuals is unified in the relevant sense when they collectivize reason.

Collective rationality is not a vague concept, but instead has a distinct and unique structure that can be precisely identified. ${ }^{\text {I23 }}$ It emerges when a group of individuals become committed to overall rational unity on a particular issue. ${ }^{\text {I24 Contradictions }}$ among the group are seen as rational inconsistencies that ought to be resolved, if possible, in much the same way as single individuals believe that rationality demands that contradictions in their own beliefs and desires ought to be resolved. ${ }^{25}$

\footnotetext{
I20 Ibid., at I I9.

I 2 I Ibid., at 95-8.

I22 See Ohlin, supra note 29, at 744-5.

I23 See, e.g., L. A. Kornhauser and L. G. Sager, 'The One and the Many: Adjudication in Collegial Courts', (I993) 8I CLR I, at IO-I3 (applying the discursive dilemma to legal contexts); C. List, 'The Discursive Dilemma and Public Reason', (2006) I I6 Ethics 362, at 398 ('structure of individual judgments underdetermines the appropriate decision at the collective level').

I 24 See C. Rovane, The Bounds of Agency: An Essay in Revisionary Metaphysics (I998), I44-5.

I 25 Ibid., at 146 .
} 
This collective rationality is particularly important when a group decides on a course of action and uses means-end reasoning to determine the appropriate steps to achieve that goal. The difference between a mere aggregation of individuals and a bona fide group exercising collective reason is that aggregate individuals with divergent beliefs will not understand them as contradictions that demand resolution. They will simply be understood as disagreements. So, under the 'collective-reason' view, only horizontal groups that exercise collective reason will have the relevant decision-making structure that allows for vicarious liability for the group's direction of the vertical hierarchical organization. The warrant for this conclusion is that the commitment to overall rational unity entails that it is really the group itself - not an individual - that is directing the affairs of the vertical organization.

It would be a mistake to view collective rationality as a simple aggregation of individual human beings engaged in individual rationality, namely a legal fiction or shorthand used to describe a large number of individuals. Under this view, the collective would have no independent significance. This argument is mistaken. The social-choice literature has amply explained that groups display a unique rational structure that cannot be re-described as an aggregation of individual rationality.

Consider a group of individuals deciding how to proceed with a given endeavour - an endeavour that can be broken down to a smaller set of decisions. One strategy is for each member of the group to individually reason towards a conclusion and then vote (or use some alternate decision procedure) on the outcome based on each individual's conclusion. There is, however, a second strategy that is far more holistic. The group as a whole can collectively decide each sub-question and then, at the end of the inquiry, let the sub-questions decide the outcome of the inquiry. If the group adopts this procedure - a form of collective reason -it cannot be explained as a large aggregation of individual decisions. It is, as it were, a form of collective rationality. ${ }^{\mathrm{I2}}$

But even collective rationality does not provide a complete normative justification for indirect perpetration; it simply provides a competitor to joint control and joint intentionality as the relevant yardstick for co-perpetration. What is needed is the missing link that explains how the vertical mode of liability can be attributed, not just to a single individual, but to an entire horizontal collective.

\subsection{The collectivist impulse}

The answer to this question is to dig deeper and emphasize what all three of these accounts have in common: a collectivist impulse. Joint control, joint intentions, and collective rationality are all doctrines that rely, implicitly, on a collective interpretation of horizontal co-operation; the doctrines differ only in how they describe that co-operation and the standards they use to measure it. If we step back from these debates for a moment and view the issue from a higher level of abstraction, it becomes clear that the collective nature of the horizontal leadership group is a common element of each of these accounts. It is the foundation upon which the more specific doctrinal differences are built.

I26 See P. Pettit, 'Collective Persons and Powers', (2002) 8 Legal Theory 443.

\section{CAMBRIDGE JDURNALS}


The collective nature of the horizontal group is precisely what I have described as a second-order linking principle. For convenience, I have described that collective principle as the 'personality principle' so as to invoke and highlight the group-agency qualities of the leadership-level group. But there is nothing essential about the language of personhood, and it does not entail a particular moral or legal conclusion about the moral worth of the leadership-level group. It simply ascribes collective agency and responsibility in just the same way as corporate personhood describes the legal and moral agency of Shell or Exxon.

Another way of describing the personality principle is to invoke the language of organizations - a terminology already used by Roxin to describe the collective nature of the vertical organization. In a similar vein, invoking the personality principle to explain the application of indirect co-perpetration means that we should also describe the leadership-level defendants as a collective organization - an entity with its own decision-making structure and a distinctive set of intentional states among its members. Vest gestures in a similar direction when he describes these defendants as 'system-functional co-perpetrators' - the notion of the 'system' embodies a collective approach to the issue. ${ }^{\text {I27 }}$ When we shift from viewing the leadership-level defendants as bare individuals to a bona fide collective, the attribution of indirect perpetration to all of them becomes all the more justifiable. This shift in thinking can be seen in the recent Lubanga Trial Chamber Judgement when the court noted that '[n]one of the participants exercises, individually, control over the crime as a whole but, instead, the control over the crime falls in the hands of a collective as such'. ${ }^{\mathrm{I} 28}$ If the collective nature of the horizontal group is playing a large role in the argument, then we need to start describing the horizontal group using the collective language of organizations or legal persons.

This naturally leads to a final objection regarding the personality principle. Criminal-law scholars are naturally and justifiably protective of the principle of culpability and its cardinal demand that punishment be strictly tailored to each defendant's individual blameworthiness. In that sense, all good criminal lawyers are individualists. Does the personality principle, as outlined in this article, threaten the principle of individual culpability (or Schuldprinzip) by allowing for guilt by association and thereby transgressing the fundamentally individualized nature of the criminal law?

The objection is misplaced. Far from promoting guilt by association, the personality principle guards against it by rendering explicit the collective nature of international crimes and the role of collectivism in the substantive doctrines applied by international courts. It is precisely for this reason that some of the most zealous guardians of the principle of culpability - think of George Fletcher, Mark Osiel, or myself - have spilled so much ink analysing doctrines of collective criminality in international criminal law, whether conspiracy, JCE, or co-perpetration. ${ }^{\text {I29 }}$

I27 See Vest, supra note 52, at 428.

I 28 See Thomas Lubanga Dyilo, supra note 98, para. 994.

I29 See, generally, G. P. Fletcher, 'The Storrs Lectures: Liberals and Romantics at War: The Problem of Collective Guilt', (2002) I I I Yale Law Journal I499; see also M. Osiel, Making Sense of Mass Atrocity (2009), 95-I02; Fletcher and Ohlin, supra note 60, at 542-5. 
Given the irreducibly collective nature of international criminal behaviour, it is best to acknowledge the normative work performed by the personality principle so that scholars and judges can properly police its fidelity to the principle of individual culpability.

\section{Conclusion}

If the personality principle is indeed the second-order linking principle behind combined vertical-horizontal modes of liability, international courts must develop and apply a workable theory to determine when the horizontal group is collective in the right sense. This issue applies not just in junta cases, but also in Katanga-and Stakić-type cases in which the defendant is held responsible for the crimes physically perpetrated by another leader's vertical organization. Both types of case require the second-order linking principle-the personality principle-to help justify the linkage of indirect perpetration with co-perpetration.

In future cases, the ICC should do more to elucidate the collective nature of the horizontal group and not just rely on a few conclusory remarks about joint control - a standard that was developed by Roxin for co-perpetration and not indirect coperpetration per se. A more advisable course of action would be to consider what makes a horizontal group collective in the relevant sense for ascribing criminal liability to all indirect co-perpetrators. The pertinent question is: what is collectivized? Is it collective control, collective intention, or collective reason? To answer this question, we first need to take the horizontal group seriously. ${ }^{130}$ There are plausible theories already developed in other disciplines - economics, philosophy, political science, and psychology - but they need to be reimported into the criminal law. A generation ago, Roxin developed Organisationsherrschaft to analyse the structure of vertical organizations and its implications for perpetration. Now this generation needs a doctrine for horizontal ones. In other words, we need more than just a theory of indirect perpetration through an organization. We need a theory of indirect perpetration by an organization - a theory that does not completely dissolve the individual into the collective mass, but charts the horizontal relationships between its members.

I30 See Fletcher, supra note 92, at 798. 